\title{
Ellagic Acid-Cyclodextrin Complexes for the Treatment of Oral Candidiasis
}

\author{
Aline da Graça Sampaio ${ }^{1}{ }^{\mathbb{D}}$, Aline Vidal Lacerda Gontijo ${ }^{1}$, Gabriela de Morais Gouvêa Lima ${ }^{1}$, \\ Maria Alcionéia Carvalho de Oliveira ${ }^{1}$, Laura Soares Souto Lepesqueur ${ }^{1,2}$ and Cristiane Yumi Koga-Ito ${ }^{1,3, *(D)}$ \\ 1 Oral Biopathology Graduate Program, São José dos Campos Institute of Science \& Technology, \\ São Paulo State University, UNESP, São Paulo 12245-000, Brazil; aline.sampaio@unesp.br (A.d.G.S.); \\ aline.gontijo@gmail.com (A.V.L.G.); gabrielademorais@yahoo.com.br (G.d.M.G.L.); \\ macoliveira12@gmail.com (M.A.C.d.O.); lalepesqueur@hotmail.com (L.S.S.L.) \\ 2 School of Dentistry, Santo Amaro University, São Paulo 04743-030, Brazil \\ 3 Department of Environment Engineering, São José dos Campos Institute of Science \& Technology, \\ São Paulo State University, UNESP, São Paulo 12247-016, Brazil \\ * Correspondence: cristiane.koga-ito@unesp.br; Tel.: +55-12-39479708
}

Citation: Sampaio, A.d.G.; Gontijo, A.V.L.; Lima, G.d.M.G.; de Oliveira, M.A.C.; Lepesqueur, L.S.S.; Koga-Ito, C.Y. Ellagic Acid-Cyclodextrin Complexes for the Treatment of Oral Candidiasis. Molecules 2021, 26, 505. https://doi.org/10.3390/

molecules26020505

Academic Editors: Rossella Grande and Simone Carradori

Received: 29 December 2020

Accepted: 14 January 2021

Published: 19 January 2021

Publisher's Note: MDPI stays neutral with regard to jurisdictional claims in published maps and institutional affiliations.

Copyright: (c) 2021 by the authors. Licensee MDPI, Basel, Switzerland. This article is an open access article distributed under the terms and conditions of the Creative Commons Attribution (CC BY) license (https:// creativecommons.org/licenses/by/ $4.0 /)$.

\begin{abstract}
The increase in the prevalence of fungal infections worldwide and the rise in the occurrence of antifungal resistance suggest that new research to discover antifungal molecules is needed. The aim of this study was to evaluate the potential use of ellagic acid-cyclodextrin complexes (EA/HP- $\beta$ $\mathrm{CD})$ for the treatment of oral candidiasis. First, the effect of EA/HP- $\beta-C D$ on $C$. albicans planktonic cells and biofilms was evaluated. Then, the cytotoxicity of the effective concentration was studied to ensure safety of in vivo testing. Finally, the in vivo effectiveness was determined by using a murine model of induced oral candidiasis. Data was statistically analyzed. The minimal inhibitory concentration of EA/HP- $\beta$-CD was $25 \mu \mathrm{g} / \mathrm{mL}$ and a concentration of 10 times MIC $(250 \mu \mathrm{g} / \mathrm{mL})$ showed an inhibitory effect on C. albicans 48 h-biofilms. The complex at concentration $250 \mu \mathrm{g} / \mathrm{mL}$ was classified as slightly cytotoxic. In vivo experiments showed a reduction in fungal epithelial invasion after treatment with EA/HP- $\beta-\mathrm{CD}$ for $24 \mathrm{~h}$ and $96 \mathrm{~h}$ when compared to the negative control. In conclusion, the results demonstrated that EA/HP- $\beta-C D$ has antifungal and anti-inflammatory effects, reducing the invasive capacity of $C$. albicans, which suggests that EA/HP- $\beta$-CD may be a promising alternative for the treatment of oral candidiasis.
\end{abstract}

Keywords: Candida albicans; oral candidiasis; ellagic acid; cyclodextrin

\section{Introduction}

Oral candidiasis affects 12 to $24.2 \%$ of immunocompromised patients and 42 to $66.7 \%$ of these cases are attributed to Candida albicans [1,2]. These infections may compromise the life of immunosuppressed patients, as the oral cavity may be a portal of entrance to systemic infections. [3]. Candidemia is related to high rates of morbidity and mortality (21.7 to $58 \%$ ) [4-6] and these rates can be even higher among patients admitted to an Intensive Care Unit [7].

Conventional antifungal drugs have several limitations such as limited spectrum of activity, interaction with other drugs, high cost, and toxicity [8]. Additionally, the increase in the occurrence of antifungal resistance is an important challenge [9-11]. Associated with this, it is also known that Candida biofilms are difficult to eradicate and they are frequently responsible for therapeutic failures $[10,12,13]$. Due to these limitations, the number of therapeutic options is very low and few molecules are used in clinical practice [14]. Thus, research for new therapies and discovery of new antifungal molecules are needed [15-17]. 
New antifungal molecules from Brazilian Pantanal plants have been reported [18-21]. Among these molecules, ellagic acid showed promising activity against Candida albicans [19].

Ellagic acid can be found in herbs, fruits, and vegetables, such as raspberries, strawberries, and walnuts [22]. These plants produce ellagic acid in the form of hydrolyzed tannins, known as ellagitannins, that present antioxidant, antimutagenic, antimicrobial, and anti-inflammatory actions [23-27]. Promsong et al. [28] suggested that this natural polyphenol can help the regeneration and improvement of mucosal innate immunity, preventing superficial infections.

Some characteristics of ellagic acid, such as the low solubility in water, limited permeability, and first pass effect can interfere with bioavailability $[19,24,29,30]$. Thus, solutions to overcome these problems and improve the pharmaceutic delivery of this molecule have been proposed [30]. One of these strategies is the inclusion of cyclodextrins. Cyclodextrins have been used to improve the solubility of drugs in water [31] and to increase the bioavailability [32-35]. They are oligosaccharide molecules and macrocycle carriers that are able to form soluble complexes with lipophilic drugs [31].

The viability of using 2-hydroxypropyl-beta-cyclodextrin (HP- $\beta-C D)$ as a carrier for ellagic acid (EA), with improvement in water solubility and dissolution, has been previously reported $[29,36,37]$. The investigation on the biological effects of ellagic acid/HP- $\beta-\mathrm{CD}$ $(\mathrm{EA} / \mathrm{HP}-\beta-\mathrm{CD})$ complex has given positive results. EA/HP- $\beta-\mathrm{CD}$ showed improved anti-inflammatory activity in vitro by increasing the protection of the erythrocyte membrane from denaturation and lysis [36]. This effect was confirmed in an in vivo study where EA/HP- $\beta-C D$ reduced significantly the edema induced by lambda carrageenan in rats [38]. Besides, EA/HP- $\beta-C D$ also showed anti-arthritis in rats, reducing the expression of pro-inflammatory cytokines [39]. Regarding antimicrobial activity, it was reported that the inclusion of EA in HP- $\beta-C D$ did not interfere with the inhibitory effect against Candida albicans, Escherichia coli, Pseudomonas aeruginosa, Bacillus luteus, and Listeria monocytogenes [29,37].

Recently, it was reported that EA/HP- $\beta$-CD reduced candida invasion in an in vitro invasive candidiasis model [29]. However, the in vivo effect of the complex has not been studied so far. Thus, the aim of this study was to evaluate the application of EA/HP- $\beta-C D$ for the treatment of oral candidiasis in a murine model. To our knowledge, this is the first comprehensive study of the effects of EA/HP- $\beta$-CD on Candida albicans biofilms, its toxicity, and application for the treatment of experimentally induced oral candidiasis.

\section{Results}

2.1. Determination of MIC of $E A$ and $E A / H P-\beta-C D$ Complex

The minimal inhibitory concentrations (MIC) of EA and EA/HP- $\beta-C D$ complex against C. albicans ATCC 18804 were $25 \mu \mathrm{g} / \mathrm{mL}$.

\subsection{Effect of EA/HP- $\beta-C D$ on C. albicans Pre-Formed Biofilms}

C. albicans ATCC 1880424 h-biofilms were not inhibited by both EA and EA/HP- $\beta$ CD. Statistically significant reduction in viability was only observed after treatment of 48 h-biofilms with EA/HP- $\beta$-CD compared with the control and pure EA (Figure 1). 


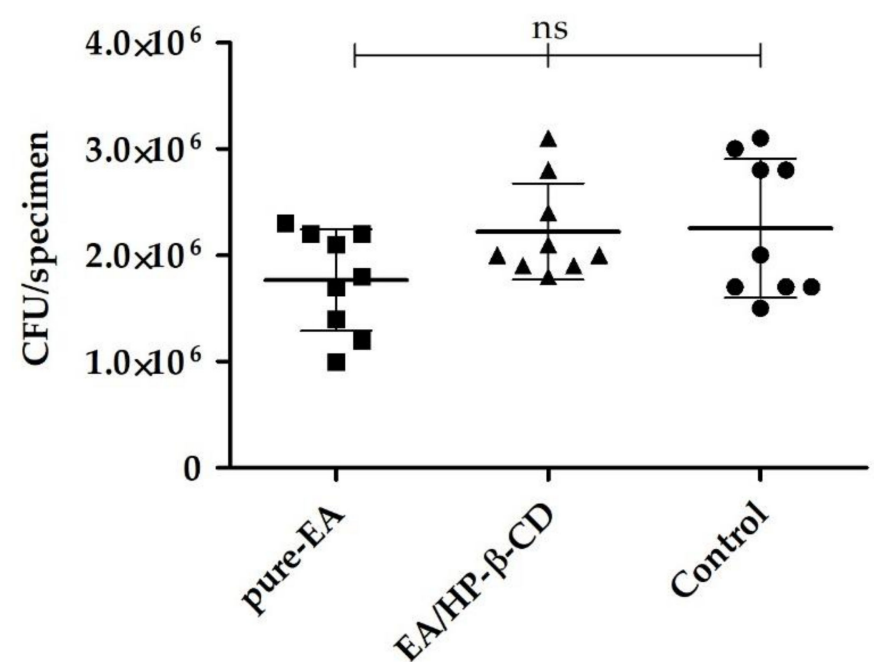

(a)

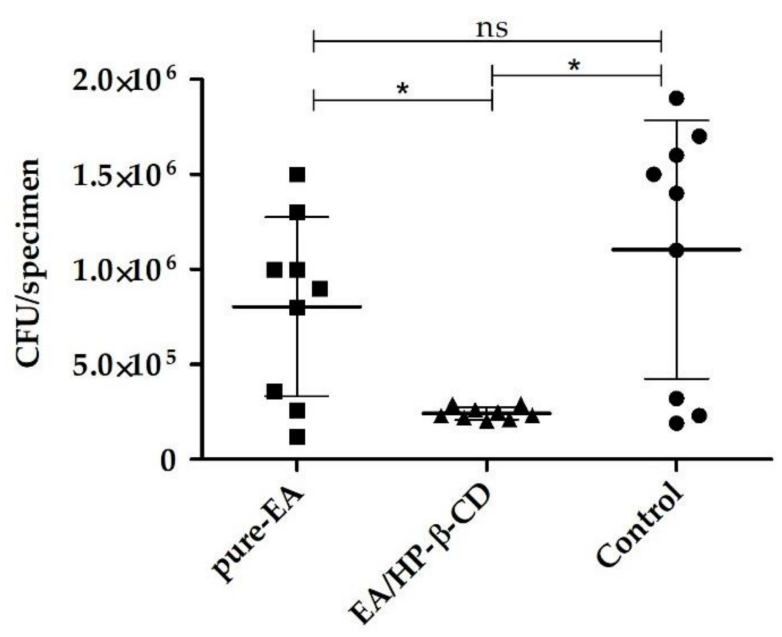

(b)

Figure 1. Effect of ellagic acid (EA) and EA/HP- $\beta$-CD on Candida albicans ATCC 18804. (a) 24 h-biofilms; (b) 48 h-biofilms. Viability after exposition to $250 \mu \mathrm{g} / \mathrm{mL}$ (10 times MIC) for $1 \mathrm{~min}$. Data was analyzed by ANOVA and Newman-Keuls multiple comparison test (n.s. $=$ not significant; ${ }^{*} p<0.05$ ).

\subsection{Toxicity Analyses}

Cytotoxicity of Ellagic Acid and EA/HP- $\beta-C D$

The toxicity of ellagic acid and EA/HP- $\beta-C D$ to fibroblast 3T3 was evaluated by MTT bioassay and the percentages of cell viability were classified according to Sletten and Dahl [40] (Figure 2). The testing concentrations were $25 \mu \mathrm{g} / \mathrm{mL}$ (MIC), $50 \mu \mathrm{g} / \mathrm{mL}$ (2 times MIC), $100 \mu \mathrm{g} / \mathrm{mL}$ (4 times MIC), and $250 \mu \mathrm{g} / \mathrm{mL}$ (10 times MIC).

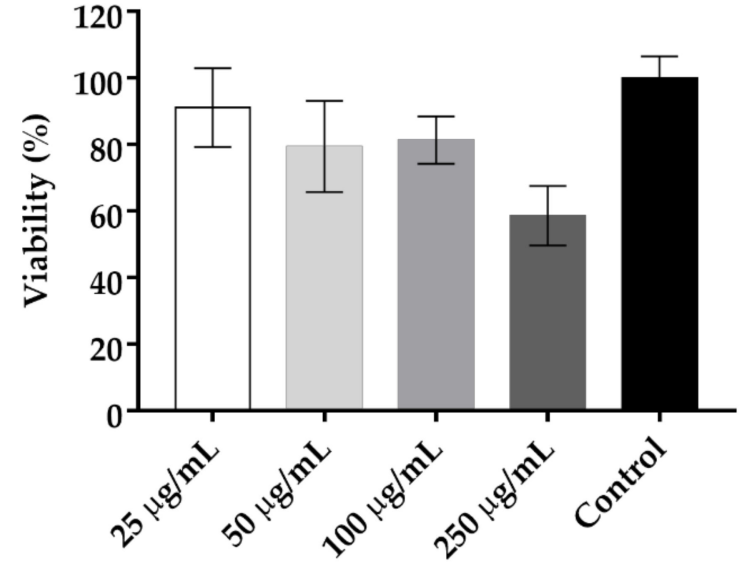

(a)

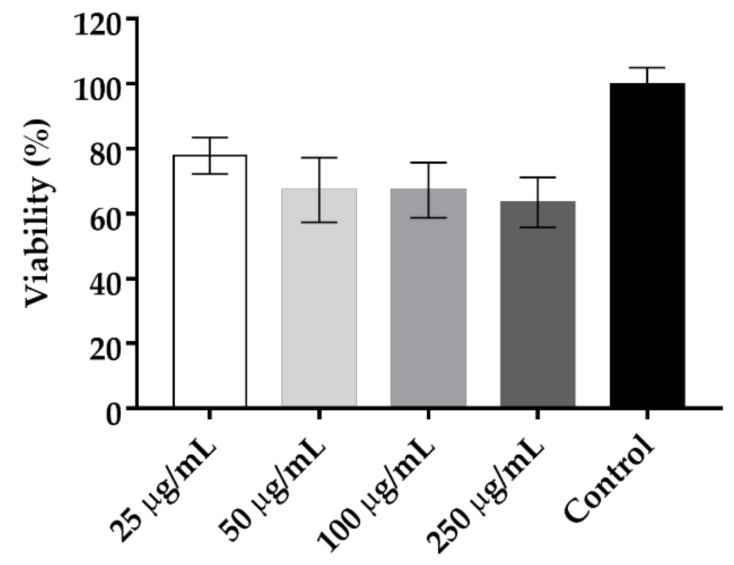

(b)

Figure 2. Viability of fibroblast $3 \mathrm{~T} 3$ after $24 \mathrm{~h}$ exposition to $25 \mu \mathrm{g} / \mathrm{mL}, 50 \mu \mathrm{g} / \mathrm{mL}, 100 \mu \mathrm{g} / \mathrm{mL}$, and $250 \mu \mathrm{g} / \mathrm{mL}$ of: (a) Non-complexed ellagic acid; (b) Complexed EA/HP- $\beta-C D$.

Non-complexed ellagic acid was classified as slightly cytotoxic at concentrations of $25 \mu \mathrm{g} / \mathrm{mL}$ and $100 \mu \mathrm{g} / \mathrm{mL}$ (91, 79 and 81\% cell viability, respectively). The concentration of $250 \mu \mathrm{g} / \mathrm{mL}$ was classified as moderately cytotoxic, with $59 \%$ cell viability.

After complexation, the cell viabilities for $25 \mu \mathrm{g} / \mathrm{mL}, 50 \mu \mathrm{g} / \mathrm{mL}$, and $100 \mu \mathrm{g} / \mathrm{mL}$, were, respectively, 77.9, 67.3, and 67.3 and were classified as slightly cytotoxic. For EA/HP- $\beta-C D$ at $250 \mu \mathrm{g} / \mathrm{mL}$ the cell viability was $63 \%$ and was thus also classified as slightly cytotoxic. 


\subsection{In Vivo Effect of EA/HP- $\beta-C D$ in the Treatment of Oral Candidiasis Experimentally Induced} in Murine Model

Complex EA/HP- $\beta$-CD containing $250 \mu \mathrm{g} / \mathrm{mL}$ of EA was used for in vivo experiments based on the antibiofilm effect on $C$. albicans. The clinical diagnosis of oral candidiasis was carried out by macroscopic analysis, and then a treatment protocol was started. Animals were treated for 3 sequential days and euthanized after $24 \mathrm{~h}$ and $96 \mathrm{~h}$ from the last treatment.

The number of viable fungal cells was quantified in the specimens collected (Figure 3). It was observed that when animals were euthanized $24 \mathrm{~h}$ after the last treatment, counts of C. albicans were $4.5 \times 10^{4} \pm 4.9 \times 10^{4}, 1.5 \times 10^{3} \pm 1.7 \times 10^{3}$, and $1.0 \times 10^{4} \pm 6.4 \times$ $10^{3} \mathrm{CFU} / \mathrm{mL}$ for control, nystatin, and EA/HP- $\beta$-CD groups. Significant differences were detected among the treatment groups (nystatin and EA/HP- $\beta-\mathrm{CD}$ ) and the control group $(p<0.05)$.

No significant differences were observed among the fungal counts obtained for animals euthanized $96 \mathrm{~h}$ after the last treatment (control-3.3 $\times 10^{3} \pm 1.7 \times 10^{3}$, nystatin-1.2 $\times 10^{4} \pm 2.0 \times 10^{4}$, and EA-4.6 $\left.\times 10^{3} \pm 5.5 \times 10^{3} \mathrm{CFU} / \mathrm{mL}\right)$.

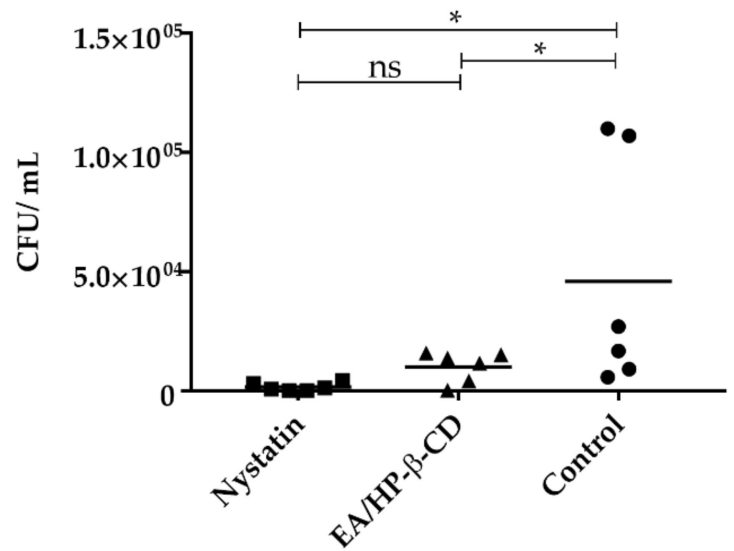

(a)

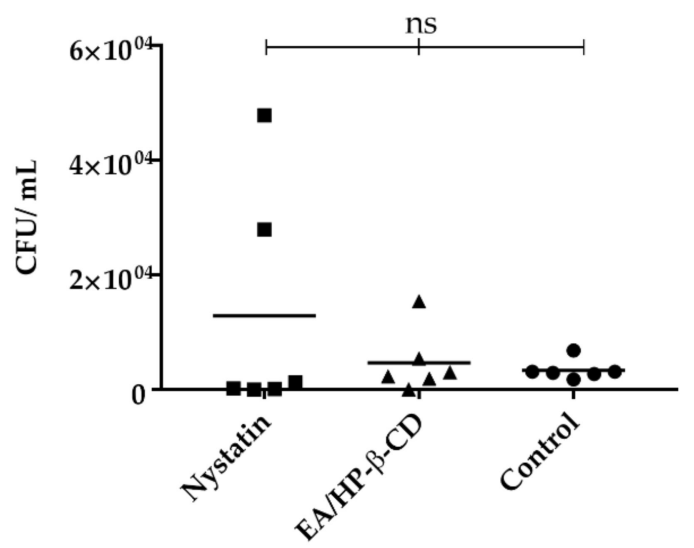

(b)

Figure 3. Number of viable fungal cells (CFU/mL) recovered: (a) 24 h; (b) 96 h; after the end of the treatment with nystatin and complex EA/HP- $\beta-C D$ in relation to negative control. Statistical test ANOVA followed by Newman-Keuls test. ${ }^{*} p<0.05$. ns-not significant.

Subsequently, the animal's tongues were analyzed histologically, by microscopic observation using $200 \times$ and $400 \times$ magnification.

Morphological analyses of Hematoxylin-Eosin (HE) (Figure 4) from the control group euthanized $24 \mathrm{~h}$ after treatment, showed hyperkeratinization of the stratified epithelium with basal layer disorganization, spongiosis, and exocytosis. The presence of lymphocytes and plasma cells, rare polymorphonuclear cells, and intense inflammatory infiltrate could be observed in the connective tissue.

The complex EA/HP- $\beta$-CD $24 \mathrm{~h}$ group exhibited inflammatory characteristics, less severe than those observed for the control group in general, but with a remarkable presence of epithelial micro-abscesses. Hyperkeratinized epithelium with preserved lingual papillae was observed. Epithelial cells did not show cell inflammatory alterations. Next to the basal layer, some areas of spongiosis could be observed. Duplication of basal layer could be seen with sparse areas of exocytosis. In the subepithelial region, increased presence of plasma cells was noted. Moderate mononuclear inflammatory infiltrate was present in the connective tissue.

In the Nystatin 24-h group, mild inflammatory alterations could be noted in a way in that the original histological characteristics were preserved. Animals showed acanthosis, alteration on the basal layer, exocytosis, and loss of papillae in candidiasis areas. In the same region mild inflammatory infiltrate was composed of lymphocytes, plasma cells, and neutrophils. 

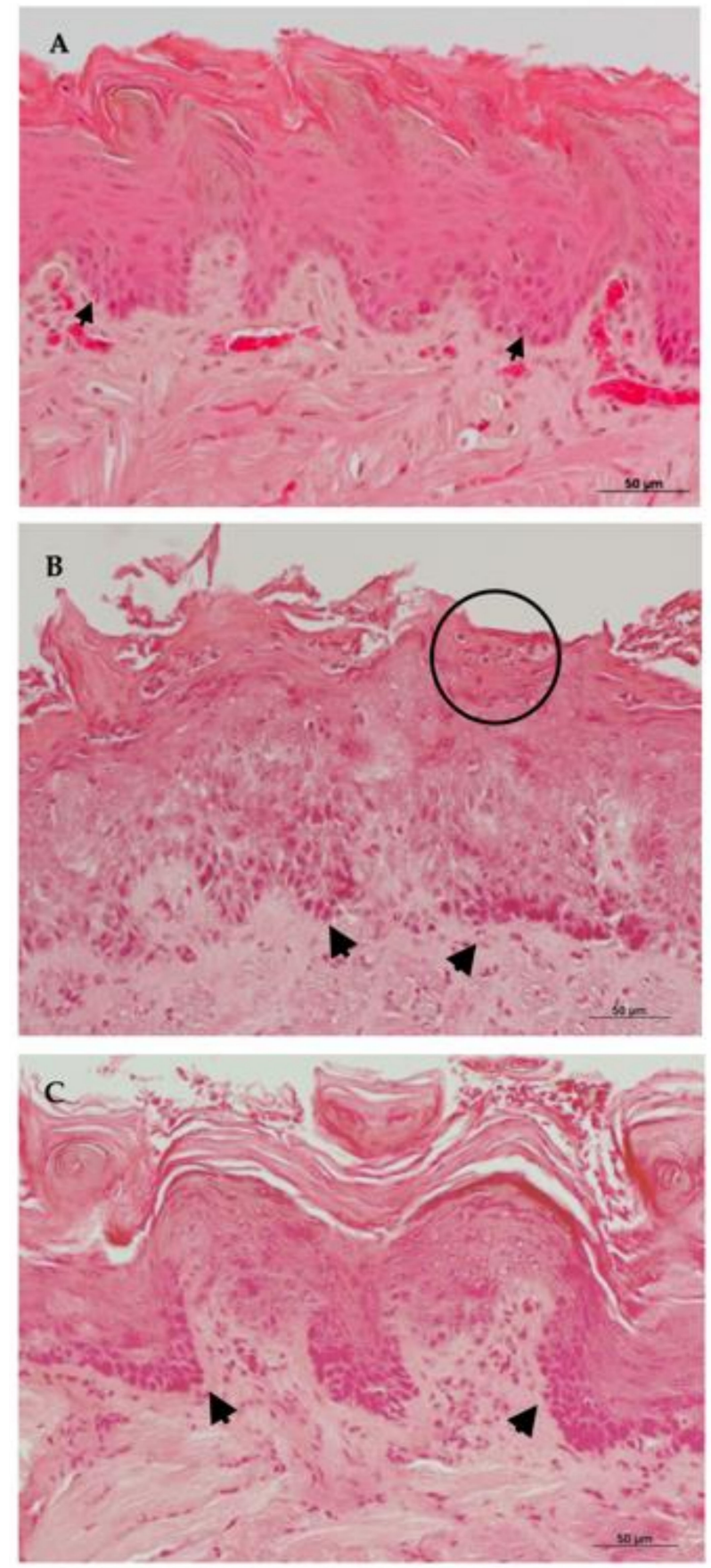

Figure 4. Histological sections from $24 \mathrm{~h}$ groups stained by Hematoxylin-Eosin (HE) in $200 \times$ magnification. Group treated with: (A) Nystatin; (B) ellagic acid complexed in HP- $\beta$-CD (EA/HP$\beta-C D)$ and $(C)$ Control Group. Arrows show alterations on the basal layer. The circle highlights micro-abscess formation in the epithelium.

In all groups analyzed, despite the manifestations of oral candidiasis, muscular, adipose and glandular tissues were preserved. Inflammatory alterations of the 24-h groups are illustrated in Figure 4.

The control group euthanized $96 \mathrm{~h}$ after treatment showed histopathologic signs of oral candidiasis. Hyperkeratinized epithelium with loss of tongue papillae and basal layer duplication could be detected. Intense mononuclear inflammatory infiltrate was observed in deeper connective tissue areas.

Tongue fragments of the HP- $\beta-C D 96 \mathrm{~h}$ group showed similar findings when compared to HP- $\beta-C D 24 \mathrm{~h}$. Mild characteristics related to candidiasis were detected. Less 
inflammatory alterations were noted. Some intra-epithelial abscesses were observed but they were small and limited to the epithelial surface. Histopathologic characteristics between the nystatin $96 \mathrm{~h}$ group were similar to that described for the nystatin $24 \mathrm{~h}$ group. Histological sections from the $96 \mathrm{~h}$ groups can be seen in Figure 5.
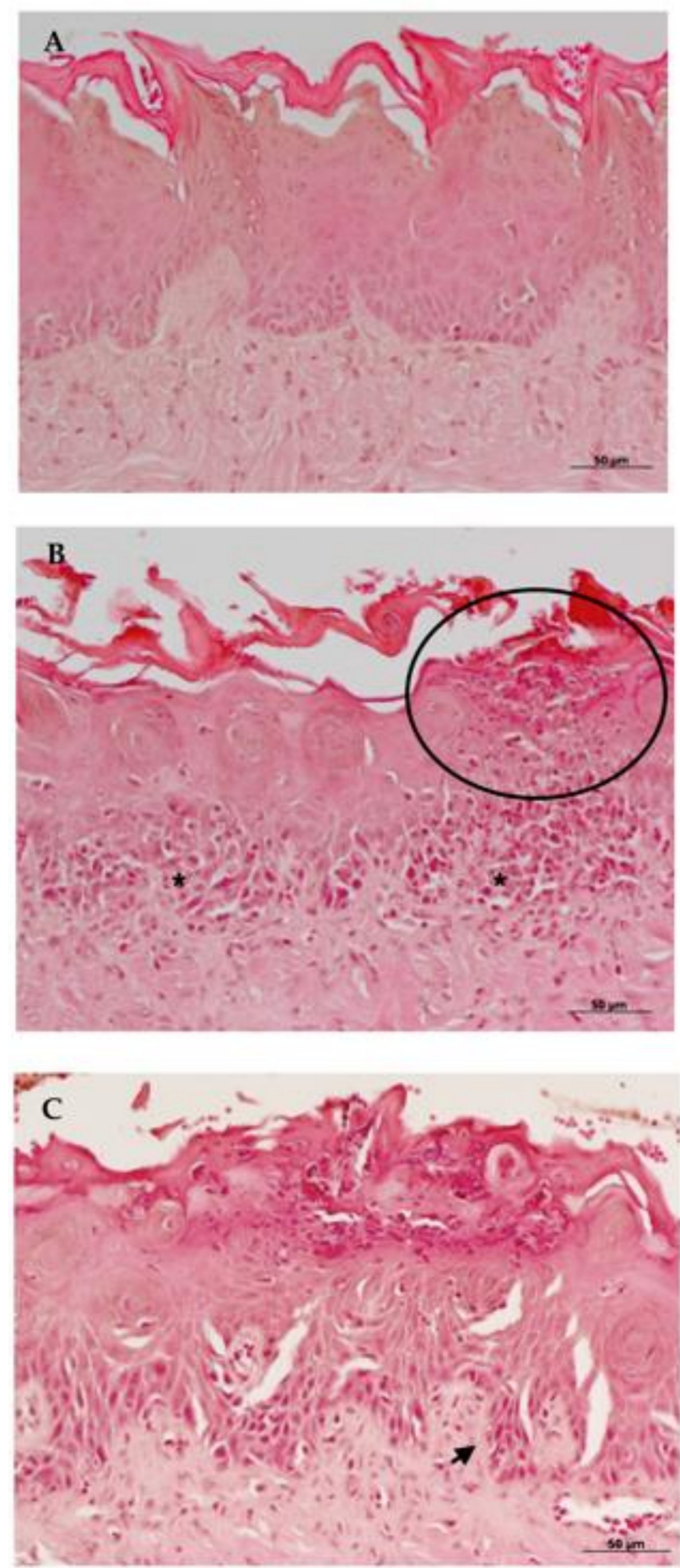

Figure 5. Histological sections from $96-\mathrm{h}$ groups stained by HE in $200 \times$ magnification. Group treated with: (A) Nystatin, (B) ellagic acid complexed in HP- $\beta-C D(E A / H P-\beta-C D)$, and (C) Control Group. Arrows show alterations on the basal layer. The circle highlights micro-abscess formation in the epithelium. $\left(^{*}\right)$ shows intense exocytosis in the basal layer of the epithelium. 
The semi quantitative analyses showed no statistical significance among the groups ( $p>0.05$; Kruskal-Wallis, following Dunn's multiple comparison test), for both periods, shown in Figure $6 c$,d. Although it was not statistically different, EA/HP- $\beta$-CD (median = 2) for both periods and the gold standard nystatin (median = 1 in the $24 \mathrm{~h}$ and 2.5 in $96 \mathrm{~h}$ ) provided minor inflammatory alterations compared to the control group (median $=2.5$ in $24 \mathrm{~h}$ and $3.5 \mathrm{in} 96 \mathrm{~h}$ ). Figure $6 \mathrm{a}, \mathrm{b}$ shows the frequency distribution for inflammatory scores.

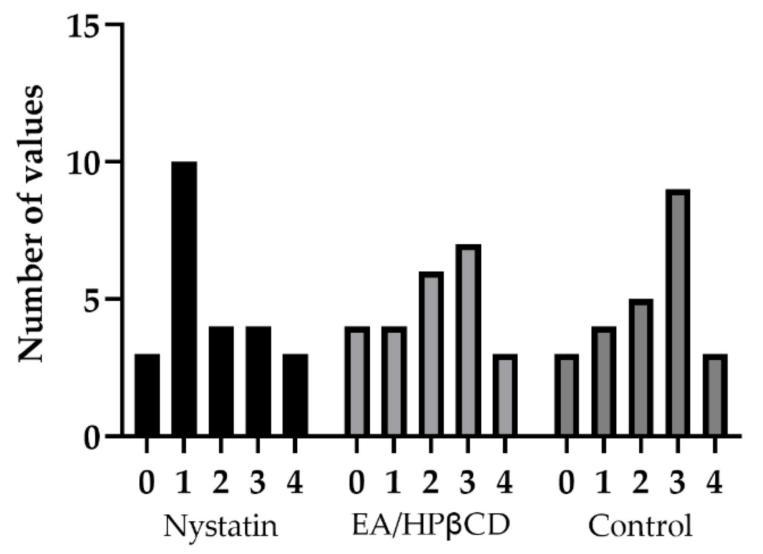

(a)

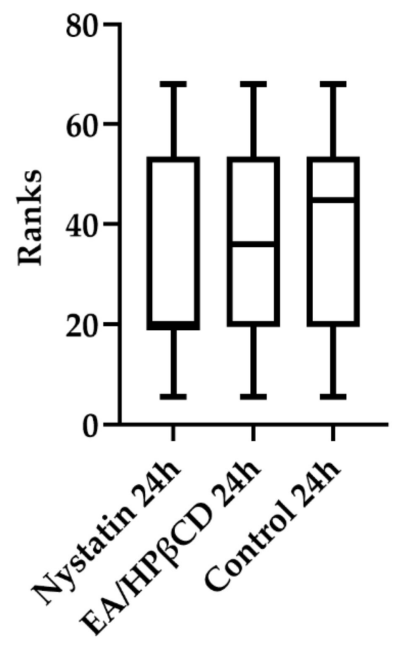

(c)

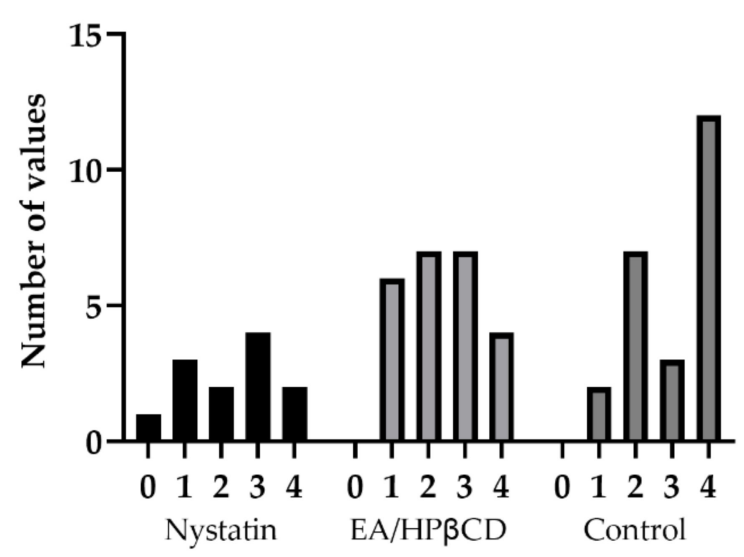

(b)

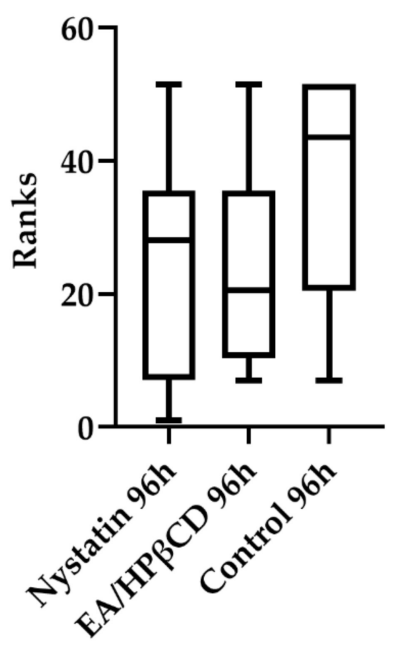

(d)

Figure 6. Frequency distribution of histological scores from groups: (a) 24 h; (b) 96 h; and ranks distribution and median from (c) $24 \mathrm{~h}$ and (d) $96 \mathrm{~h}$.

PAS analyses after $24 \mathrm{~h}$ of the last treatment showed that complex EA/HP- $\beta-\mathrm{CD}$ group (median $=0$ ) could reduce tissue invasion by Candida hyphae and there was a significant difference in the amount of Candida hyphae invading the tissue when compared to negative control (median $=2)($ Figure 7$)$. The nystatin group $($ median $=1)$ also showed significant difference and lower invasion when compared to negative control. $(p<0.0001$; Kruskal-Wallis, followed Dunn's multiple comparison test), in shown in Figure 8. After $96 \mathrm{~h}$ of the last treatment showed significant difference of the control (median $=1$ ) between the complex EA/HP- $\beta-C D$ group and nystatin group. In the nystatin group and complex $\mathrm{EA} / \mathrm{HP}-\beta-\mathrm{CD}$ the score median was $=0$. 

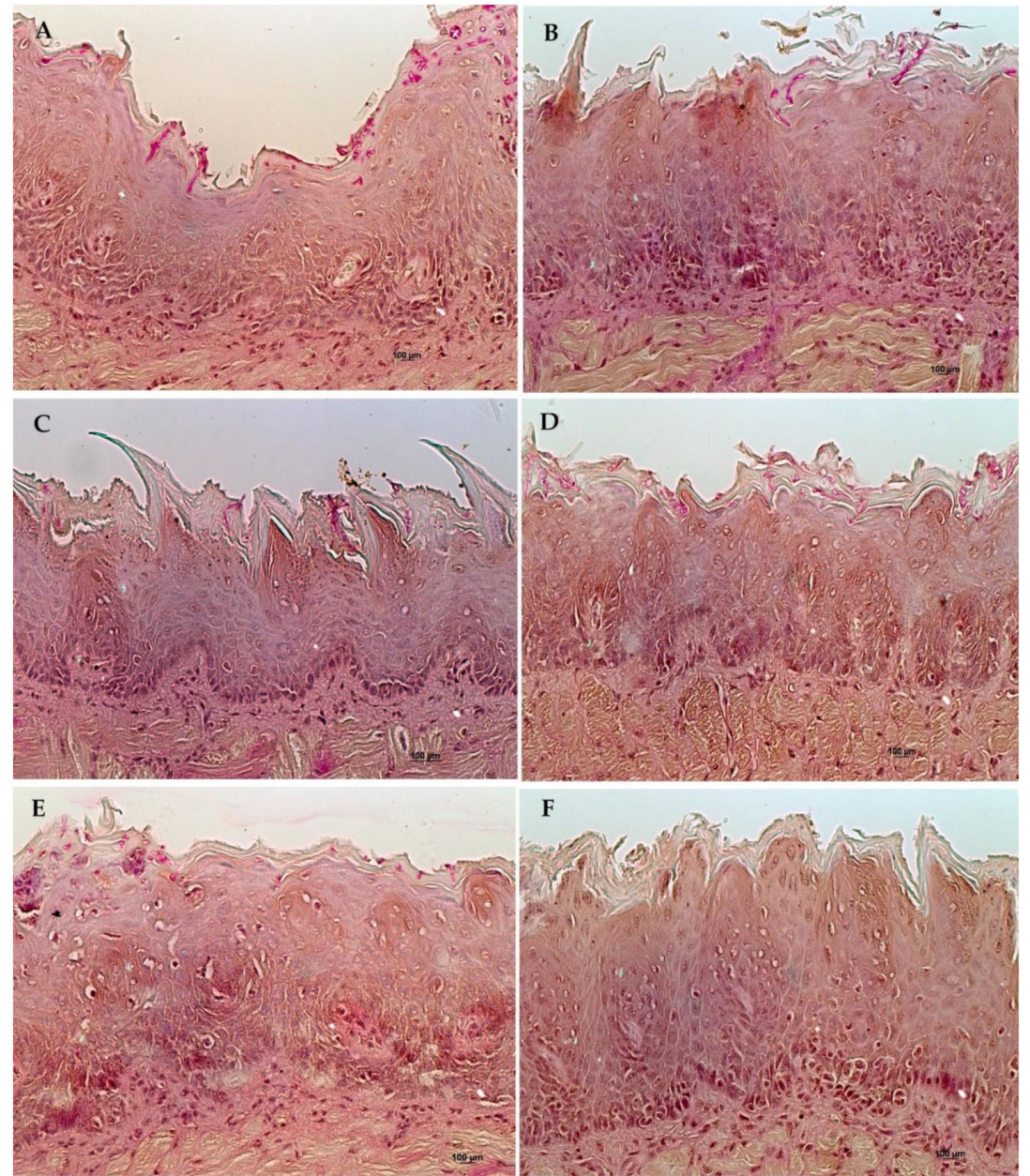

Figure 7. Histological sections stained by Periodic acid-Schiff (PAS) in $200 \times$ magnification. Group treated with Nystatin: (A) 24 h; (B) 96 h; group treated with ellagic acid complexed in HP- $\beta-C D$

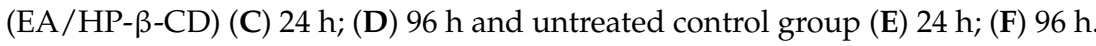

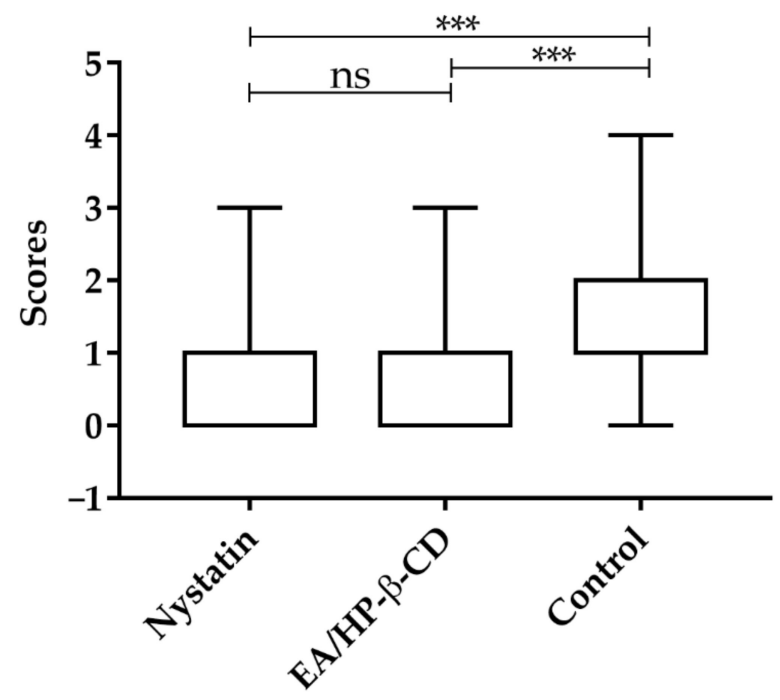

(a)

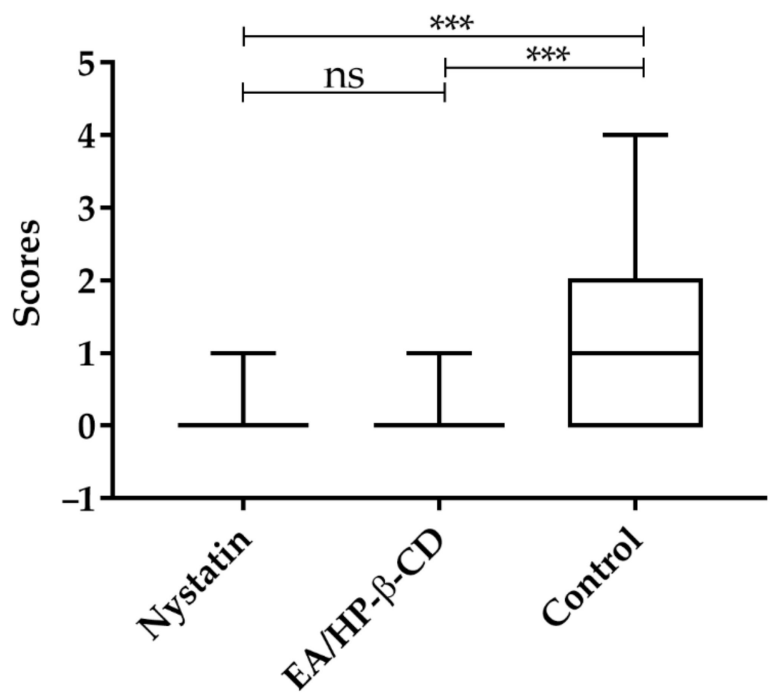

(b)

Figure 8. Scores (median values) of the histological analysis of Candida hyphae invading the epithelium after: (a) $24 \mathrm{~h}$; (b) $96 \mathrm{~h}$; from the last treatment. Statistical test was ANOVA followed by Kruskal-Wallis and multiple comparison Dunn's test. *** $p<0.0001$. ns-not significant. 


\section{Discussion}

Previous studies indicated a promising inhibitory action of EA on Candida albicans [19]. Gontijo et al. [29] evaluated the action of ellagic acid complexed with cyclodextrin in an in vitro invasive candidiasis model and obtained a reduction of fungal invasion. Candida's resistance to conventional antifungals such as azoles. polyenes, and echinocandins, are recurrent, requiring the search for new therapeutic treatments against this fungus [41-43]. However, there are no data on the in vivo effect of this molecule for the treatment of oral candidiasis.

As reported in the literature, EA has poor aqueous solubility $[23,24,37,44]$ and the cell membrane has low permeability to EA [37], which can compromise its bioavailability. Cyclodextrin was thus used in order to improve its solubility. The cyclodextrin used in the present study, hydroxypropyl beta-cyclodextrin (HP- $\beta-C D)$, was selected because it is one of the most used and has the ability to provide better complexation results according to the literature [32]. The HP- $\beta-\mathrm{CD}$ molecule has hydroxypropyl groups in its formula that can result in a large increase in solubility of up to $60 \%$ mass by volume $(\mathrm{m} / \mathrm{v})$, compared to other cyclodextrins, such as $\beta-\mathrm{CD}$, which usually produce insoluble or low complex solubility [32,45-47]. The complexation process and characterization of the complex were described in a previous study [29].

The antibiofilm action of the isolated molecule and the EA/HP- $\beta-C D$ complex was initially evaluated. The concentration 10 times MIC $(250 \mu \mathrm{g} / \mathrm{mL})$ was chosen since biofilms are more resistant to antimicrobial agents than planktonic cells. Thus, higher concentrations than MIC are usually necessary to be more effective against Candida biofilms, as previously described in the literature $[48,49]$. Therefore, concentrations lower or higher than 10 times MIC $(250 \mu \mathrm{g} / \mathrm{mL})$ would probably be, respectively, less effective and toxic or insoluble in culture medium. In these experiments, it was found that EA/HP- $\beta-C D$ at a concentration of $250 \mu \mathrm{g} / \mathrm{mL}$ had an effect against a biofilm of $48 \mathrm{~h}$. However, this result was not observed for 24-h biofilms. Since biofilm maturation occurs between 24 and $48 \mathrm{~h}$, forming a more complex and increased multi-layer matrix with all fungal cells present [50], the greater activity in mature biofilms was unexpected. This result is similar to that reported by Teodoro et al. [47], using gallic acid. It is known that the properties of a biofilm formed in $24 \mathrm{~h}$ differ from a biofilm in $48 \mathrm{~h}$, such as the molecular characteristics and water content [51]. Possibly, these differences associated with the different components of the biofilm matrix may be associated with the better performance of the compounds on biofilms of $48 \mathrm{~h}$ [52]. The distribution of the drug is aided by the presence of water channels in the structure of the biofilm and the components of the biofilm matrix can delay this access [52]. Drug diffusion rates may be distinct when comparing biofilms formed by different strains of C. albicans, which is further evidence that the effectiveness of a molecule can be influenced by many factors related to the specificities of each biofilm [52].

A cytotoxicity test was carried out in order to evaluate the cell viability as a function of different concentrations. The effect on fibroblasts was investigated. Pure and complexed ellagic acid demonstrated moderate and slight cytotoxicity, respectively, at the highest tested concentration of $250 \mu \mathrm{g} / \mathrm{mL}$, according to a previous study [40], showing cell viability of 58 to $63 \%$, respectively. The results corroborate the study by Lourenção Brighenti et al. [19], in which non-complexed ellagic acid also did not show cytotoxicity, with $80 \%$ cell viability after $24 \mathrm{~h}$ of exposure to a concentration of $50 \mu \mathrm{g} / \mathrm{mL}$. In the present study, at the same concentration $(50 \mu \mathrm{g} / \mathrm{mL})$, a similar value of $79.4 \%$ of cell viability was found in the pure substance and $67.3 \%$ in the substance containing HP- $\beta-C D$. Cytotoxicity tests on different cell lines, such as rat embryonic fibroblast (NIH/ 3T3) and Madin-Darky bovine kidney (MDBK) and human foreskin fibroblast (HFF) showed that cell viabilities were equal or more than $50 \%$ at concentrations equal or higher than $790 \mu \mathrm{M}(238.6 \mu \mathrm{g} / \mathrm{mL})$ after $24 \mathrm{~h}$ of exposure for EA complexed in $\beta$-CD [53]. Furthermore, the complexation with $\beta$-CD did not affect cell viability [53], as observed in this present study. A similar finding was observed by Weisburg et al., [54] that did not observe cytotoxicity in normal human gingival fibroblasts (HF-1) at a concentration of $200 \mu \mathrm{M}(60.4 \mu \mathrm{g} / \mathrm{mL})$ after $24 \mathrm{~h}$ 
of exposure. Although further studies should be carried out to determine the chronic toxicity of EA/HP- $\beta-C D$, these sets of findings suggest the safe use of EA following its administration, even at higher concentrations, which is a potential advantage for its use on biofilms. Indeed, the required concentration to disrupt biofilms could be several times the MIC [48]. Therefore, further experiments were performed with concentrations 10 times the $\operatorname{MIC}(250 \mu \mathrm{g} / \mathrm{mL})$.

Owing to the low cytotoxicity and the promising antibiofilm activity of EA/HP- $\beta-\mathrm{CD}$ complex containing $250 \mu \mathrm{g} / \mathrm{mL}$ of EA, an in vivo study with mice was performed with this new formulation at this concentration to evaluate its effect for the treatment of oral candidiasis. The application of this new formulation was selected since candidiasis is the most common infection in oral mucosa, especially in immunocompromised patients [55]. Additionally, topic administration of this formulation has an advantage from a biopharmaceutical point of view, in that as EA crosses the membrane slowly [29], the effect will be probably limited to a local tissue, which would reduce possible systemic side effects.

The methodology of inducing oral candidiasis in mice proved to be effective, validated by the characteristic lesions on the tongue and corroborated by the observation of hyphae and yeasts in the histopathological analysis. It is important to highlight that the occurrence of a disease is the involvement of the complex interaction between the microorganism and the host, involving the expression of Candida virulence factors, the interactions of the bacterial microbiome and the host's own immune system [56]. Thus, in vivo model studies become important for the validation of results obtained in vitro and for the generation of data to support future clinical use.

Similarly, to the reduction of viable cells in a 48-h biofilm treated with EA/HP- $\beta$ $\mathrm{CD}$ detected in vitro, a significant reduction in the colony forming unit (CFU) count of C. albicans was observed in the tongues of animals with experimentally induced oral candidiasis after $24 \mathrm{~h}$ of the last treatment, but not significant for the tissue inflammatory response.

In the present project, EA/HP- $\beta-C D$ was applied topically, twice a day, for three days. This multidose regimen is recommended for nystatin, considered the gold standard for the treatment of oral candidiasis [42]. It should be noted that treatment with nystatin for oral candidiasis can vary from 1 to 4 weeks and there is no consensus on the formulation, dosage, or duration of treatment [57]. Quindós et al. [58] highlighted that the Infectious Diseases Society of America (IDSA) recommends nystatin in doses ranging from 4-6 mL (liquid drug) four times a day, or the administration of 1-2 lozenges, four times a day for 7-14 days for the treatment of mild oral candidiasis. Thus, the dosage of nystatin can vary between 100,000 U to 200,000 U. However, Lyu et al. [57], demonstrated that nystatin at a dosage of 400,000 $\mathrm{U}$ has better effects on fungi. Thus, future studies, increasing the number of treatment days, could be performed to seek a better response to nystatin and $\mathrm{EA} / \mathrm{HP}-\beta-\mathrm{CD}$. Besides, the association of EA/HP- $\beta-\mathrm{CD}$ and other conventional antifungals should be investigated.

The histopathological analyses of the animals' tongues submitted to the induction of experimental oral candidiasis indicated a reduction in the tissue invasion of hyphae of $C$. albicans to the epithelium, in the groups exposed to the treatments of ellagic acid complexed in HP- $\beta-C D$ and nystatin, after both treatment times, when compared to the non-treated control.

The groups treated with EA complexed in cyclodextrin, reached similar levels of tissue invasion in relation to the group treated with nystatin, after $24 \mathrm{~h}$. After $96 \mathrm{~h}$, the group treated with nystatin showed the highest reduction when compared to the EA/HP- $\beta-C D$ group. The histopathologic analyses of the treated groups showed less inflammatory alterations and better conservation of the tissue characteristics than the control group. These effects were more evident after $96 \mathrm{~h}$ of treatment, although the median values of the histological scores were not statistically significant. These findings corroborate previous in vitro studies that reported the anti-inflammatory and antimicrobial effect of EA treatment [23-25]. 
Oral topical application of EA/HP- $\beta$-CD reduced fungal tissue invasion and had an anti-inflammatory effect. These outcomes suggest that the complex has the potential to be used clinically for the treatment of oral candidiasis, particularly in refractory cases and when there is resistance to conventional antifungals. Future investigations on other therapeutic regimens and association with conventional antifungals may reveal new potentials for the clinical use of EA/HP- $\beta-C D$.

\section{Materials and Methods}

4.1. EA/HP- $\beta$-CD Complex Formation and Determination of Minimal Inhibitory Concentration (MIC) of $E A$ and $E A / H P-\beta-C D$

The complexation of ellagic acid and characterization of EA/HP- $\beta-C D$ were previously described by Gontijo [29]. The minimal inhibitory concentration (MIC) of pure EA and EA/HP- $\beta$-CD complex were determined for Candida albicans ATCC 18804. The MIC assessment was performed according to the microdilution technique describe in the M27-A3 standard document by Clinical Laboratory Standards Institute (CLSI) [59]. The inoculum was standardized spectrophotometrically $(\lambda: 530 \mathrm{~nm}$ and O.D.: 0.138$)$, obtaining approximately $10^{6}$ cells $/ \mathrm{mL}$. This suspension was diluted in Roswell Park Memorial Institute medium (RPMI) 160 broth ( $\mathrm{pH} \mathrm{7.0)}$ to obtain a concentration of $10^{3}$ cells $/ \mathrm{mL}$. EA concentrations between 50 and $0.08 \mu \mathrm{g} / \mathrm{mL}$ were tested. The plates were incubated for $24 \mathrm{~h}$ at $37^{\circ} \mathrm{C}$, in aerobiosis. Fungal growth was analyzed visually and compared to the positive control. The MIC was determined as the concentration inhibiting $80 \%$ of growth compared to the control.

\subsection{Effect of $E A / H P-\beta-C D$ on $C$. albicans Pre-Formed Biofilms}

The antibiofilm effect of EA/HP- $\beta$-CD was evaluated according to the methodology of Cheng et al. [60], with modifications. EA/HP- $\beta$-CD (10 times MIC, $250 \mu \mathrm{g} / \mathrm{mL})$ and pure EA $(250 \mu \mathrm{g} / \mathrm{mL})$ were tested. Briefly, standardized C. albicans ATCC 18804 suspension in a concentration of $10^{7}$ cells $/ \mathrm{mL}$ was obtained spectrophotometrically. Aliquots of $20 \mu \mathrm{L}$ of the fungal inoculum was added to $180 \mu \mathrm{L}$ RPMI broth supplemented with glucose $2 \%$ in 96 well plates. Plates were incubated for $90 \mathrm{~min}$ at $37^{\circ} \mathrm{C}$, under shaking $(80 \mathrm{rpm})$, for the pre-adhesion phase. After this period, each well was washed with sterile saline solution ( $\mathrm{NaCl} 0.9 \%$ ) and fresh culture medium was added. Biofilms of 24 and $48 \mathrm{~h}$ were obtained. For $48 \mathrm{~h}$ biofilms, the culture medium was refreshed after $24 \mathrm{~h}$ incubation.

Biofilms were exposed to EA/HP- $\beta-C D(250 \mu \mathrm{g} / \mathrm{mL})$ and pure EA $(250 \mu \mathrm{g} / \mathrm{mL})$ for $1 \mathrm{~min}$ at room temperature. Non-exposed growth control was included for comparative purposes. Then, the biofilms were washed with sterile physiologic solution ( $\mathrm{NaCl} 0.9 \%$ ). The biofilms were dispersed, serially diluted, and plated on Sabouraud dextrose agar. Plates were incubated at $37^{\circ} \mathrm{C}$ for $24 \mathrm{~h}$. After the incubation period, the number of colony forming units (CFU) per biofilm was obtained. The tests were performed in triplicate on 3 different occasions.

\subsection{Toxicity Analyzes \\ Cytotoxicity of Ellagic Acid and EA/HP- $\beta-C D$}

Fibroblasts 3T3 were cultivated in Dulbecco modified Eagle medium (DMEM) supplemented with 10\% inactivated bovine fetal serum and penicillin/streptomycin $1 \%$ and maintained at $37^{\circ} \mathrm{C}$ and $5 \% \mathrm{CO}_{2}$. The cells $\left(6 \times 10^{4}\right.$ cells/well, passages 13 and 17) were transferred to 96 -well microplates and incubated at $37{ }^{\circ} \mathrm{C}, 5 \% \mathrm{CO}_{2}$ for $24 \mathrm{~h}$. Then, the culture medium was removed and the cells were treated with pure EA or EA/HP$\beta$-CD complex, previously solubilized in DMEM at different concentrations, from 25 to $250 \mu \mathrm{g} / \mathrm{mL}$. The microplates were incubated at $37^{\circ} \mathrm{C}, 5 \% \mathrm{CO}_{2}$ for $24 \mathrm{~h}$. Cell bioactivity was measured by MTT according to Mosmann [61]. Non-treated cells and DMEM medium were used as controls. The bioactivity was determined by comparing the percentage of cell viability, considering the non-treated group as $100 \%$. The assays were performed in triplicate on 2 different occasions. The treatment was classified according to the final cell 
viability as severely cytotoxic (less than 30\%), moderately cytotoxic (between 30 and 60\%), and slightly cytotoxic (greater than 60\%), according to Sletten and Dahl [40].

4.4. In Vivo Effect of EA/HP- $\beta-C D$ in the Treatment of Oral Candidiasis Experimentally Induced in Murine Model Structures

The methodology of experimentally induced oral candidiasis was based on Okada [62] and Borges [63], with modifications.

Thirty male mice (Mus musculus, Swiss), with 55 days and approximately $45 \mathrm{~g}$ of weight were randomly divided into 3 groups, according to the treatment: (i) Complex EA/HP- $\beta$-CD containing $250 \mu \mathrm{g} / \mathrm{mL}$ of EA; (ii) Positive control-Nystatin solution 100,000 UI/mL (Nystatin, Neoquímica, Rio de Janeiro, Brazil); and (iii) Negative controlPBS phosphate buffered saline ( $\mathrm{pH} 7.4$ ).

Animals were immunosuppressed with prednisolone $(100 \mathrm{mg} / \mathrm{kg}$ Depro-Medrol, Pfizer, Belgium), each $48 \mathrm{~h}$ for up to 5 days. A solution of tetracycline $(0.83 \mathrm{mg} / \mathrm{mL}$; Terracimina, Zoetis, Guarulhos, São Paulo, Brazil) was added to the drinking water in all the experimental periods. Treatment with prednisolone and tetracycline started one day before the experimental infection. Animals were maintained at controlled environmental conditions (temperature at $20^{\circ} \mathrm{C}$ and $12 \mathrm{~h}$ light cycle in ventilated racks and received water and food ad libitum).

C. albicans ATCC 18804 standardized suspensions $\left(10^{8}\right.$ cells $\left./ \mathrm{mL}\right)$ were prepared in a spectrophotometer ( $\lambda: 530 \mathrm{~nm}$ and O.D.: 1.258). Animals were anesthetized with $10 \%$ ketamin (Dopalen, $0.2 \mathrm{~mL} / 100 \mathrm{~g}$ body weight; Ceva, Paulínia, Brazil) and 2\% xylazine (Anasedan, $0.1 \mathrm{~mL} / 100 \mathrm{~g}$ body weight; Ceva, Brazil). The animals were inoculated with sterile swabs soaked with fungal suspension for $5 \mathrm{~min}$ in contact with the mice's tongue. Inoculation was performed on days 2 and 4 of the experiment. The diagnosis of candidiasis was done $48 \mathrm{~h}$ after the last inoculation. Animals with clinical diagnosed lesions were divided into the experimental groups ( $n=10$ each group).

Treatments were administered twice a day ( 8 a.m. and 2 p.m.), intra-orally using micropipettes, for 3 days in non-anesthetized animals. After 24 and $96 \mathrm{~h}$ from the last treatment, animals were submitted to euthanasia with excessive dose of anesthetic. Tongues were removed and microbiologic and histological analyzes were performed. The experimental arrangement is illustrated in Figure 9.

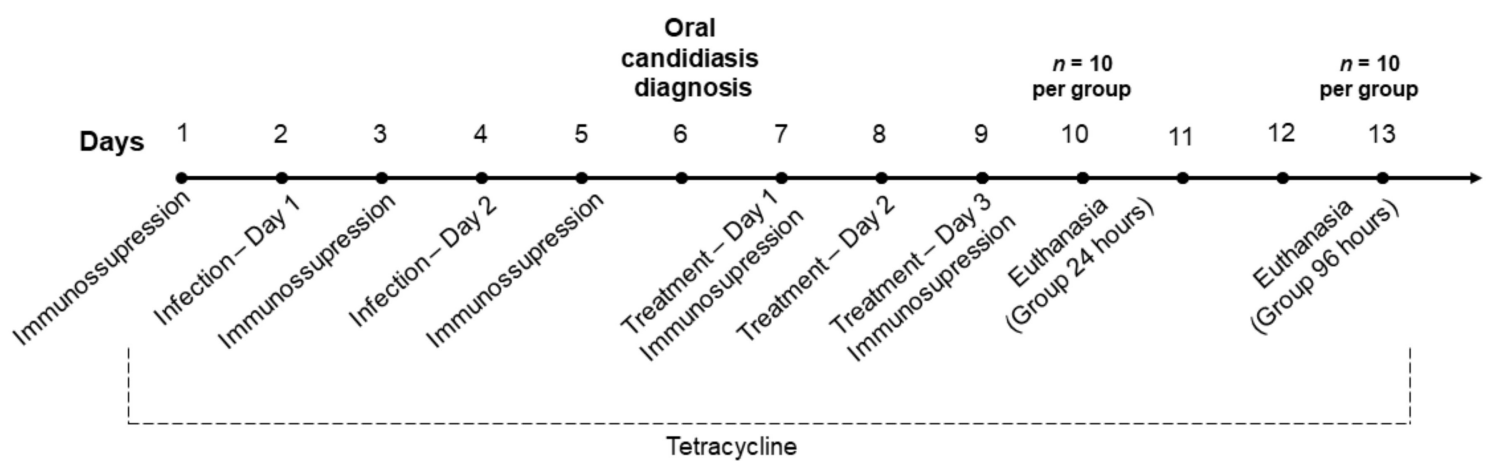

Figure 9. Timeline of the experimental procedure.

Six animals of each group were randomly selected for microbiologic analyses of the tongue. Tongues were removed, macerated, and treated with a solution of $0.25 \%$ trypsin for $20 \mathrm{~min}$, according to [64]. The final suspension was plated in Sabouraud dextrose agar supplemented with chloramphenicol and for $\mathrm{CFU} /$ tongue values were calculated.

Tongues from 4 animals per group were prepared for histopathological analyses. After being surgically removed, the tongues were fixed in $4 \%$ paraformaldehyde solution, processed, and embedded in paraffin. Slices of 5 microns were obtained and stained with PAS (Periodic acid-Schiff) and HE (Hematoxylin-Eosin), aiming to observe fungal 
invasion and tissue alterations, respectively. All the analyses were performed with optical microscopy by a single examiner.

For PAS analyzes, two slices per animal were analyzed, for a total of 42 fields per tongue. The number of invading hyphae was counted in all fields and the counts were scored: $0-$ absence of hyphae; $1-1$ to 5 hyphae; $2-6-15$ hyphae; $3-16$ to 50 hyphae; and 4-more than 50 hyphae [65].

For HE analyzes, the slices were observed in distinct fields at 200x and 400x magnification (Axioskop 40, Carl Zeiss, Oberkochen, Germany) for descriptive analyses of the tissue inflammatory response. Scores were attributed according to the number and type of inflammatory epithelial alterations (6 fields/tongue). Presence of hyperkeratosis, hyperplasia, acanthosis, exocytosis, spongiosis, alteration in the basal layer pattern, loss of lingual papillae, and presence of intraepithelial micro abscess were assessed and scores were attributed according to Table 1.

Table 1. Score of inflammatory epithelial alterations.

\begin{tabular}{cc}
\hline Score & Classification \\
\hline 0 & No alteration \\
1 & Hyperkeratosis or Hyperplasia \\
2 & Hyperkeratosis +2 inflammatory alterations \\
3 & Hyperkeratosis +3 inflammatory alterations including papillae rectification \\
4 & Micro abscess + inflammatory alterations \\
\hline
\end{tabular}

\subsection{Data Analyses}

All the experiments were previously analyzed by normality test followed by suitable statistical analysis. Statistical analyses and graphs were performed using GraphPad Prism, version 7.0 (Graphpad Software Inc., San Diego, CA, USA). The results of antibiofilm effects were compared by One-way ANOVA followed by Newman-Keuls multiple comparison post-hoc test. The values of cytotoxicity were obtained by percentage analysis. For the in vivo assays, microbiological data was analyzed with One-way ANOVA test, followed by Newman-Keuls multiple comparison post-hoc test. Histological (PAS and HE) scores (median values) were analyzed by Kruskal-Wallis with Dunn's post hoc tests. The significance level was determined as $5 \%$.

\section{Conclusions}

In conclusion, the results demonstrated that the EA/HP- $\beta-C D$ has antifungal and anti-inflammatory effects, showing a reduction in the invasive capacity of $C$. albicans, which suggests that EA/HP- $\beta-C D$ may be a promising alternative for the treatment of oral candidiasis.

Author Contributions: Conceptualization, C.Y.K.-I. and A.V.L.G.; methodology, A.d.G.S., A.V.L.G., G.d.M.G.L., M.A.C.d.O., L.S.S.L., C.Y.K.-I.; software, A.d.G.S.; validation, A.d.G.S., A.V.L.G., G.d.M.G.L, M.A.C.d.O., L.S.S.L., C.Y.K.-I.; formal analysis, A.d.G.S., A.V.L.G., G.d.M.G.L., M.A.C.d.O., L.S.S.L., C.Y.K.-I.; investigation, A.d.G.S., A.V.L.G., G.d.M.G.L., M.A.C.d.O., L.S.S.L., C.Y.K.-I.; resources, C.Y.K.-I.; data curation, A.d.G.S., A.V.L.G., G.d.M.G.L.; writing-original draft preparation, A.d.G.S., A.V.L.G., G.d.M.G.L., C.Y.K.-I.; writing—review and editing, A.d.G.S., A.V.L.G., G.d.M.G.L., M.A.C.d.O., L.S.S.L., C.Y.K.-I.; visualization, A.d.G.S.; supervision, A.V.L.G., G.d.M.G.L., C.Y.K.-I.; project administration, C.Y.K.-I.; funding acquisition, C.Y.K.-I. All authors have read and agreed to the published version of the manuscript.

Funding: This research was funded by São Paulo Research Foundation (FAPESP), Grants 16/212017-0 and 2016/07196-6; and National Council for Scientific and Technological Development (308127/20188). This study was financed in part by the Coordenação de Aperfeiçoamento de Pessoal de Nível Superior, Brasil (CAPES), Finance Code 001.

Institutional Review Board Statement: The protocol of the experiment was previously approved by Local Ethical Committee for research involving animals (Process \#05/2017). 
Informed Consent Statement: Not applicable.

Data Availability Statement: The data presented in this study are available on request from the corresponding author.

Acknowledgments: The authors thank Clelia Aparecida Paiva for technical assistance.

Conflicts of Interest: The authors declare no conflict of interest.

Sample Availability: Samples of the compounds are available from the authors.

\section{References}

1. Spalanzani, R.N.; Mattos, K.; Marques, L.I.; Barros, P.F.D.; Pereira, P.I.P.; Paniago, A.M.M.; Mendes, R.P.; Chang, M.R. Clinical and Laboratorial Features of Oral Candidiasis in HIV-Positive Patients. Rev. Soc. Bras. Med. Trop. 2018, 51, 352-356. [CrossRef]

2. Santos, S.B.D.; Sabadin, C.E.S.; Mario, D.N.; Rigo, L.; Barbosa, D.A. Presence of Candida Spp. and Candidiasis in Liver Transplant Patients. An. Bras. Dermatol. 2018, 93, 356-361. [PubMed]

3. Senpuku, H.; Sogame, A.; Inoshita, E.; Tsuha, Y.; Miyazaki, H.; Hanada, N. Systemic Diseases in Association with Microbial Species in Oral Biofilm from Elderly Requiring Care. Gerontology 2003, 49, 301-309. [CrossRef]

4. Castanheira, M.; Deshpande, L.M.; Davis, A.P.; Rhomberg, P.R.; Pfaller, M.A. Monitoring Antifungal Resistance in a Global Collection of Invasive Yeasts and Molds: Application of CLSI Epidemiological Cutoff Values and Whole-Genome Sequencing Analysis for Detection of Azole Resistance in Candida Albicans. Antimicrob. Agents Chemother. 2017, 61, 1-20. [CrossRef]

5. Nucci, M.; Braga, P.R.; Nouér, S.A.; Anaissie, E. Time of Catheter Removal in Candidemia and Mortality. Braz. J. Infect. Dis. 2018, 22, 455-461. [CrossRef]

6. Jia, X.; Li, C.; Cao, J.; Wu, X.; Zhang, L. Clinical Characteristics and Predictors of Mortality in Patients with Candidemia: A Six-Year Retrospective Study. Eur. J. Clin. Microbiol. Infect. Dis. 2018, 37, 1717-1724. [CrossRef]

7. Ghrenassia, E.; Mokart, D.; Mayaux, J.; Demoule, A.; Rezine, I.; Kerhuel, L.; Calvet, L.; De Jong, A.; Azoulay, E.; Darmon, M. Candidemia in Critically Ill Immunocompromised Patients: Report of a Retrospective Multicenter Cohort Study. Ann. Intensive Care 2019, 9, 62. [CrossRef]

8. Bondaryk, M.; Kurzatkowski, W.; Staniszewska, M. Antifungal Agents Commonly Used in the Superficial and Mucosal Candidiasis Treatment: Mode of Action and Resistance Development. Postep. Dermatol. Alergol. 2013, 30, 293-301. [CrossRef]

9. Hirota, K.; Yumoto, H.; Sapaar, B.; Matsuo, T.; Ichikawa, T.; Miyake, Y. Pathogenic Factors in Candida Biofilm-Related Infectious Diseases. J. Appl. Microbiol. 2016, 122, 321-330. [CrossRef]

10. Nett, J.E. Future Directions for Anti-Biofilm Therapeutics Targeting Candida. Expert Rev. Anti. Infect. Ther. 2014, 12, 375-382. [CrossRef]

11. Patil, S.; Majumdar, B.; Sarode, S.C.; Sarode, G.S.; Awan, K.H. Oropharyngeal Candidosis in HIV-Infected Patients-An Update. Front. Microbiol. 2018, 9, 1-9. [CrossRef]

12. Chandra, J.; Mukherjee, P.K. Candida Biofilms: Development, Architecture and Resistance. Microbiol. Spectr. 2015, 3, 1-24. [CrossRef]

13. Lohse, M.B.; Gulati, M.; Johnson, A.D.; Nobile, C.J. Development and Regulation of Single- and Multi-Species Candida Albicans Biofilms. Nat. Rev. Microbiol. 2018, 16, 19-31. [CrossRef]

14. Roemer, T.; Krysan, D.J. Antifungal Drug Development: Challenges, Unmet Clinical Needs, and New Approaches. Cold Spring Harb. Perspect. Med. 2014, 4, a019703. [CrossRef]

15. Taff, H.T.; Mitchell, K.F.; Edward, J.A.; Andes, D.R. Mechanisms of Candida Biofilm Drug Resistance. Future Microbiol. 2013, 8 , 1325-1337. [CrossRef]

16. Sobel, J.D.; Sobel, R. Current Treatment Options for Vulvovaginal Candidiasis Caused by Azole-Resistant Candida Species. Expert Opin. Pharmacother. 2018, 19, 971-977. [CrossRef]

17. Zida, A.; Bamba, S.; Yacouba, A.; Ouedraogo-Traore, R.; Guiguemdé, R.T. Anti- Candida Albicans Natural Products, Sources of New Antifungal Drugs: A Review. J. Mycol. Med. 2017, 27, 1-19. [CrossRef]

18. Brighenti, F.L.; Salvador, M.J.; Delbem, A.C.B.; Delbem, Á.C.B.; Oliveira, M.A.C.; Soares, C.P.; Freitas, L.S.F.; Koga-Ito, C.Y. Systematic Screening of Plant Extracts from the Brazilian Pantanal with Antimicrobial Activity against Bacteria with Cariogenic Relevance. Caries Res. 2014, 48, 353-360. [CrossRef]

19. Brighenti, F.L.; Salvador, M.J.; Gontijo, A.V.L.; Delbem, A.C.B.; Delbem, Á.C.B.; Soares, C.P.; De Oliveira, M.A.C.; Girondi, C.M.; Koga-Ito, C.Y. Plant Extracts: Initial Screening, Identification of Bioactive Compounds and Effect against Candida Albicans Biofilms. Future Microbiol. 2017, 12, 15-27. [CrossRef]

20. Teodoro, G.R.; Ellepola, K.; Seneviratne, C.J.; Koga-Ito, C.Y. Potential Use of Phenolic Acids as Anti-Candida Agents: A Review. Front. Microbiol. 2015, 6, 1-11. [CrossRef]

21. Teodoro, G.R.; Brighenti, F.L.; Delbem, A.C.B.; Delbem, Á.C.B.; Khouri, S.; Gontijo, A.V.L.; Pascoal, A.C.R.F.; Salvador, M.J.; Koga-Ito, C.Y. Antifungal Activity of Extracts and Isolated Compounds from Buchenavia Tomentosa on Candida Albicans and Non-Albicans. Future Microbiol. 2015, 10, 917-927. [CrossRef]

22. Shakeri, A.; Zirak, M.R.; Sahebkar, A. Ellagic Acid: A Logical Lead for Drug Development? Curr. Pharm. Des. 2018, 24, 106-122. [CrossRef] 
23. Bala, I.; Bhardwaj, V.; Hariharan, S.; Kharade, S.V.; Roy, N.; Ravi, M.N.V. Sustained Release Nanoparticulate Formulation Containing Antioxidant- Ellagic Acid as Potential Prophylaxis System for Oral Administration. J. Drug Target 2006, 14, 27-34. [CrossRef]

24. Bala, I.; Bhardwaj, V.; Hariharan, S.; Kumar, M.N.V.R. Analytical Methods for Assay of Ellagic Acid and Its Solubility Studies. J. Pharm. Biomed. Anal. 2006, 40, 206-210. [CrossRef]

25. Nittayananta, W. Oral Fungi in HIV: Challenges in Antifungal Therapies. Oral Dis. 2016, 22, 107-113. [CrossRef]

26. Ríos, J.-L.; Giner, R.; Marín, M.; Recio, M. A Pharmacological Update of Ellagic Acid. Planta Med. 2018, 84, 1068-1093. [CrossRef]

27. Alfei, S.; Turrini, F.; Catena, S.; Zunin, P.; Grilli, M.; Pittaluga, A.M.; Boggia, R. Ellagic Acid a Multi-Target Bioactive Compound for Drug Discovery in CNS? A Narrative Review. Eur. J. Med. Chem. 2019, 183, 111724. [CrossRef]

28. Promsong, A.; Chung, W.O.; Satthakarn, S.; Nittayananta, W. Ellagic Acid Modulates the Expression of Oral Innate Immune Mediators: Potential Role in Mucosal Protection. J. Oral Pathol. Med. 2015, 44, 214-221. [CrossRef]

29. Gontijo, A.V.; Da G Sampaio, A.; Koga-Ito, C.Y.; Salvador, M.J. Biopharmaceutical and Antifungal Properties of Ellagic AcidCyclodextrin Using an in Vitro Model of Invasive Candidiasis. Future Microbiol. 2019, 14, 957-967. [CrossRef]

30. Zuccari, G.; Baldassari, S.; Ailuno, G.; Turrini, F.; Alfei, S.; Caviglioli, G. Formulation Strategies to Improve Oral Bioavailability of Ellagic Acid. Appl. Sci. 2020, 10, 3353. [CrossRef]

31. Challa, R.; Alka, A.; Javed, A.; Khar, R. Cyclodextrins in Drug Delivery: An Updated Review. AAPS PharmSciTech 2005, 6, E329-E357. [CrossRef]

32. Loftsson, T.; Hreinsdóttir, D.; Stefánsson, E. Cyclodextrin Microparticles for Drug Delivery to the Posterior Segment of the Eye: Aqueous Dexamethasone Eye Drops. J. Pharm. Pharmacol. 2007, 59, 629-635. [CrossRef]

33. Loftsson, T.; Konrádsdóttir, F.; Másson, M. Influence of Aqueous Diffusion Layer on Passive Drug Diffusion from Aqueous Cyclodextrin Solutions through Biological Membranes. Pharmazie 2006, 61, 83-89. [PubMed]

34. Teixeira, K.I.R.; Araújo, P.V.; Neves, B.R.A.; Mahecha, G.A.B.; Sinisterra, R.D.; Cortés, M.E. Ultrastructural Changes in Bacterial Membranes Induced by Nano-Assemblies $\beta$-Cyclodextrin Chlorhexidine: SEM, AFM, and TEM Evaluation. Pharm. Dev. Technol. 2013, 18, 600-608. [CrossRef]

35. Teixeira, K.I.R. Estudo Das Alterações Da Membrana Celular de Microrganismos Por Compostos de Inclusão de Clorexidina: Beta-Ciclodextrina Em Diferentes Proporções Molares Usando Microscopia de Força Atômica e Microscopia Eletrônica de Varredura. Ph.D. Thesis, Universidade Federal de Minas Gerais, Belo Horizonte, Brazil, 25 April 2008.

36. Bulani, V.D.; Kothavade, P.S.; Kundaikar, H.S.; Gawali, N.B.; Chowdhury, A.A.; Degani, M.S.; Juvekar, A.R. Inclusion Complex of Ellagic Acid with $\beta$-Cyclodextrin: Characterization and in Vitro Anti-Inflammatory Evaluation. J. Mol. Struct. 2016, 1105, 308-315. [CrossRef]

37. Savic, I.M.; Jocic, E.; Nikolic, V.D.; Popsavin, M.M.; Rakic, S.J.; Savic-Gajic, I.M. The Effect of Complexation with Cyclodextrins on the Antioxidant and Antimicrobial Activity of Ellagic Acid. Pharm. Dev. Technol. 2019, 24, 410-418. [CrossRef]

38. Bulani, V.D.; Kothavade, P.S.; Nagmoti, D.M.; Kundaikar, H.S.; Degani, M.S.; Juvekar, A.R. Characterisation and AntiInflammatory Evaluation of the Inclusion Complex of Ellagic Acid with Hydroxypropyl- $\beta$-Cyclodextrin. J. Incl. Phenom. Macrocycl. Chem. 2015, 82, 361-372. [CrossRef]

39. Bulani, V.; Kothavade, P.; Nagmoti, D.; Juvekar, A. Ellagic Acid Hydroxypropyl-ß-Cyclodextrin Inclusion Complex Alleviates Adjuvant-Induced Arthritis: Attenuation of Oxidative Stress and Inflammatory Mediators. Cytokine 2014, 70, 32. [CrossRef]

40. Sletten, G.B.G.; Dahl, J.E. Cytotoxic Effects of Extracts of Compomers. Acta Odontol. Scand. 1999, 57, 316-322. [CrossRef]

41. Pristov, K.E.; Ghannoum, M.A. Resistance of Candida to Azoles and Echinocandins Worldwide. Clin. Microbiol. Infect. 2019, 25, 792-798. [CrossRef]

42. Scheibler, E.; Garcia, M.C.R.; Da Silva, R.M.; Figueiredo, M.A.; Salum, F.G.; Cherubini, K. Use of Nystatin and Chlorhexidine in Oral Medicine: Properties, Indications and Pitfalls with Focus on Geriatric Patients. Gerodontology 2017, 34, 291-298. [CrossRef]

43. Viljoen, J.; Azie, N.; Schmitt-Hoffmann, A.-H.; Ghannoum, M. A Phase 2, Randomized, Double-Blind, Multicenter Trial To Evaluate the Safety and Efficacy of Three Dosing Regimens of Isavuconazole Compared with Fluconazole in Patients with Uncomplicated Esophageal Candidiasis. Antimicrob. Agents Chemother. 2015, 59, 1671-1679. [CrossRef]

44. Lei, F.; Xing, D.M.; Xiang, L.; Zhao, Y.N.; Wang, W.; Zhang, L.J.; Du, L.J. Pharmacokinetic Study of Ellagic Acid in Rat after Oral Administration of Pomegranate Leaf Extract. J. Chromatogr. B Anal. Technol. Biomed. Life Sci. 2003, 796, 189-194. [CrossRef]

45. Loftsson, T.; Jarho, P.; Másson, M.J.T. Cyclodextrins in Drug Delivery System. Expert. Opin Drug. Deliv. 2005. [CrossRef]

46. Loftsson, T.; Brewster, M.E. Pharmaceutical Applications of Cyclodextrins. 1. Drug Solubilization and Stabilization. J. Pharm. Sci. 1996, 85, 1017-1025. [CrossRef]

47. Teodoro, G.R.; Gontijo, A.V.L.; Borges, A.C.; Tanaka, M.H.; De Morais Gouvêa Lima, G.; Salvador, M.J.; Koga-Ito, C.Y. Gallic Acid/Hydroxypropyl- $\beta$-Cyclodextrin Complex: Improving Solubility for Application on in Vitro/in Vivo Candida Albicans Biofilms. PLoS ONE 2017, 12, e0181199. [CrossRef]

48. Rajendran, R.; Sherry, L.; Nile, C.J.; Sherriff, A.; Johnson, E.M.; Hanson, M.F.; Williams, C.; Munro, C.A.; Jones, B.J.; Ramage, G. Biofilm Formation Is a Risk Factor for Mortality in Patients with Candida Albicans Bloodstream Infection-Scotland, $2012-2013$. Clin. Microbiol. Infect. 2016, 22, 87-93. [CrossRef]

49. Romera, D.; Aguilera-Correa, J.J.; Gadea, I.; Viñuela-Sandoval, L.; García-Rodríguez, J.; Esteban, J. Candida Auris: A Comparison between Planktonic and Biofilm Susceptibility to Antifungal Drugs. J. Med. Microbiol. 2019, 68, 1353-1358. [CrossRef] 
50. Ramage, G.; Vandewalle, K.; Wickes, B.L.; López-Ribot, J.L. Characteristics of Biofilm Formation by Candida Albicans. Rev. Iberoam. Micol. 2001, 18, 163-170.

51. Sheppard, D.C.; Howell, P.L. Biofilm Exopolysaccharides of Pathogenic Fungi: Lessons from Bacteria. J. Biol. Chem. 2016, 291, 12529-12537. [CrossRef]

52. Al-Fattani, M.A.; Douglas, L.J. Biofilm Matrix of Candida Albicans and Candida Tropicalis: Chemical Composition and Role in Drug Resistance. J. Med. Microbiol. 2006, 55, 999-1008. [CrossRef]

53. Beshbishy, A.M.; Batiha, G.E.-S.; Yokoyama, N.; Igarashi, I. Ellagic Acid Microspheres Restrict the Growth of Babesia and Theileria in Vitro and Babesia Microti in Vivo. Parasit. Vectors 2019, 12, 269. [CrossRef]

54. Weisburg, J.H.; Schuck, A.G.; Reiss, S.E.; Wolf, B.J.; Fertel, S.R.; Zuckerbraun, H.L.; Babich, H. Ellagic Acid, a Dietary Polyphenol, Selectively Cytotoxic to HSC-2 Oral Carcinoma Cells. Anticancer Res. 2013, 33, 1829-1836. [PubMed]

55. Kong, E.F.; Kucharíková, S.; Van Dijck, P.; Peters, B.M.; Shirtliff, M.E.; Jabra-Rizk, M.A. Clinical Implications of Oral Candidiasis: Host Tissue Damage and Disseminated Bacterial Disease. Infect. Immun. 2015, 83, 604-613. [CrossRef]

56. Höfs, S.; Mogavero, S.; Hube, B. Interaction of Candida Albicans with Host Cells: Virulence Factors, Host Defense, Escape Strategies, and the Microbiota. J. Microbiol. 2016, 54, 149-169. [CrossRef]

57. Lyu, X.; Zhao, C.; Yan, Z.M.; Hua, H. Efficacy of Nystatin for the Treatment of Oral Candidiasis: A Systematic Review and Meta-Analysis. Drug Des. Devel. Ther. 2016, 10, 1161-1171. [CrossRef]

58. Quindos, G.; Gil-Alonso, S.; Marcos-Arias, C.; Sevillano, E.; Mateo, E.; Jauregizar, N.; Eraso, E. Therapeutic Tools for Oral Candidiasis: Current and New Antifungal Drugs. Med. Oral Patol. Oral Cir. Bucal 2019, 24, e172. [CrossRef]

59. CLSI. Reference method for broth dilution antifungal susceptibility testing of yeast: Approved standard. In Clinical and Laboratory Standards Institute; Clinical and Laboratory Standards Institute: Wayne, PA, USA, 2008.

60. Cheng, L.; Exterkate, R.A.M.; Zhou, X.; Li, J.; Cate, J.M.T. Effect of Galla Chinensis on Growth and Metabolism of Microcosm Biofilms. Caries Res. 2011, 45, 87-92. [CrossRef]

61. Mosmann, T. Rapid Colorimetric Assay for Cellular Growth and Survival: Application to Proliferation and Cytotoxicity Assays. J. Immunol. Methods 1983, 65, 55-63. [CrossRef]

62. Okada, M.; Hisajima, T.; Ishibashi, H.; Miyasaka, T.; Abe, S.; Satoh, T. Pathological Analysis of the Candida Albicans-Infected Tongue Tissues of a Murine Oral Candidiasis Model in the Early Infection Stage. Arch. Oral Biol. 2013, 58, 444-450. [CrossRef]

63. Borges, A.C.; De Morais Gouvêa Lima, G.; Nishime, T.M.C.; Gontijo, A.V.L.; Kostov, K.G.; Koga-Ito, C.Y. Amplitude-Modulated Cold Atmospheric Pressure Plasma Jet for Treatment of Oral CANDIDIASIS: In Vivo Study. PLoS ONE 2018, 13, e0199832. [CrossRef]

64. Hayama, K.; Maruyama, N.; Abe, S. Cell Preparation Method with Trypsin Digestion for Counting of Colony Forming Units in Candida Albicans-Infected Mucosal Tissues. Med. Mycol. 2012, 87, 858-862. [CrossRef]

65. Junqueira, J.C.; Colombo, C.E.D.; da Silva Martins, J.; Ito, C.Y.K.; Carvalho, Y.R.; Jorge, A.O.C. Experimental Candidosis and Recovery of Candida Albicans from the Oral Cavity of Ovariectomized Rats. Microbiol. Immunol. 2005, 49, 199-207. [CrossRef] 